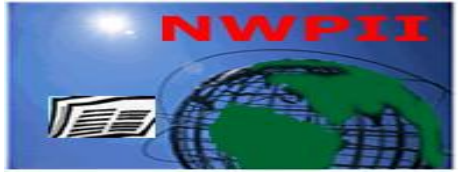

\title{
Comparative Histoarchitectural and Biochemical Studies of the Hippocampus in Peroxisome Proliferative Activated Receptor Gamma Agonist Treated Insulin Resistant Rats
}

\section{Ajayi Stephen Olawale ${ }^{1}$, Iliya Ezekiel ${ }^{1}$, Ejike Daniel Eze $^{2^{*}}$, Idowu Oluwamayowa ${ }^{3}$, Moses Dele Adams ${ }^{4}$, Karimah Mohammed Rabiu ${ }^{5}$ and Prisca Ojochogu Ajeka ${ }^{6}$} \author{
Box 71, Ishaka-Bushenyi, Uganda. \\ ${ }^{3}$ Department of Anatomy, Faculty of Basic Medical Sciences, University of Lagos, Nigeria. \\ Nigeria. \\ "Corresponding Author \\ Ejike Daniel Eze, $\mathrm{PhD}$ \\ Senior Lecturer, Department of Physiology, Kampala International University, \\ Western Campus, P. O. Box 71, \\ Ishaka - Bushenyi \\ Uganda \\ Tel: +256782975042 \\ Email: daneze4@gmail.com
}

${ }^{1}$ Department of Biological Sciences, Faculty of Pure and Applied Sciences, Federal University, Wukari, Nigeria.

${ }^{2}$ Department of Physiology, Faculty of Biomedical Sciences, Kampala International University, Western Campus, P.O.

${ }^{4}$ Department of Biochemistry, Faculty of Computing and Applied Sciences, Baze University, Abuja, Nigeria.

${ }^{5}$ Department of Biological Sciences, Faculty of Science, Yobe State University, Damaturu, Yobe, Nigeria.

${ }^{6}$ Department of Human Kinetics and Sports Science, Alvan Ikoku Federal College of Education, Owerri, Imo State,

Received:28 August 2019; | Revised:05 November 2019; | Accepted:07 March 2020

\section{Abstract}

Background: The currently prescribed anti-diabetic drugs have been clinically proven to develop resistance to reduce the elevated blood glucose level, reduce haemoglobin A1c (HbA1) concentration, possess insulin insensitivity issues as well as other pharmacokinetic disturbances.

Aim: To evaluate the activity of peroxisome proliferative activated receptor (PPRA) gamma agonist; pioglitazone and fenofibrate treated insulin resistant rats.

Materials and Methods: Apparently healthy male rats were intraperitoneally injected into diabetes with STZ (30 mg/kg b. w.) for five days and fed with diet rich in fat for 8 weeks. Pioglitazone $(20 \mathrm{mg} / \mathrm{kg} \mathrm{b}$. w.) and fenofibrate $(10 \mathrm{mg} / \mathrm{kg} \mathrm{b}$. w.) was administered by oral gavage to rats which are obese and resistant to insulin for 15 consecutive days. Over the last 7 days, blood collected intraperitoneally was used to test for glucose and insulin tolerance as well as gluconeogenesis. At the end of 15 days experimental treatment period, blood collected was used for biochemical assay whereas in the liver and skeletal muscle, glucose transporter 4 (GLUT4) and insulin receptor substrate -1 (IRS-1) protein expression were assayed for using immune-histochemistry.

Result: The low-dose STZ and HFD - induced obese rats showed significant $(p<0.05)$ insulin resistance and obesity when compared with the control animals. Treatment of test group animals with $20 \mathrm{mg} / \mathrm{kg} \mathrm{b}$. W. of 
pioglitazone and $10 \mathrm{mg} / \mathrm{kg}$ b. w. of fenofibrate statistically $(\mathrm{p}<0.05)$ lowered levels of blood insulin, triglyceride and free fatty acid but raised the concentration of high-density lipoprotein-cholesterol (HDL-C). Also, there was appreciable $(\mathrm{p}<0.05)$ reduction in lipid content of the liver and muscle following treatment with pioglitazone and fenofibrate. The skeletal muscle GLUT4 count as well as liver and skeletal muscle IRS-1 protein contents were sufficiently $(p<0.05)$ elevated.

Conclusion: Results gathered from the study suggest improved sensitivity of insulin in low-dose STZ and HFD-induced obese rats following treatment with pioglitazone and fenofibrate. The insulin sensitizing activity in the animals by pioglitazone and fenofibrate may be due to inhibition of gluconeogenesis, amelioration of lipid metabolism, reduction in hyperinsulinemia as well as elevation of IRS-1 and GLUT4 protein expression in insulin-sensitive tissues.

Keywords:Type 2 diabetes mellitus, Hippocampus, PPAR-gamma, Pioglitazone, Fenofibrate

Abbreviation: DM: Diabetes mellitus; IDE: Insulin degrading enzyme; GLUT4: Glucose transporter 4; ICV: intracerebroventricular; STZ: Streptozotocin; TZD: thiazolidinedione; CNS: central nervous system; T2DM: Type 2 diabetes mellitus; PPAR gamma: Peroxisome proliferator-activated receptor gamma; HbA 1c: Haemoglobin A1c; CA: Cornu Ammonis; BBB: blood - brain barrier; HFD: High-fat diet; MWM: Morris water maze; PBS: Phosphate buffered saline; IR: Insulin resistance

\section{Introduction}

Neuroinflammation is regarded as swelling of the nervous tissue. It could commence in response to a number of cues, which includes traumatic brain damage, mild infection, harmful metabolites, or autoimmunity. In the central nervous system (CNS), which comprises the brain and neuronal cords, microglia are the resident innate white blood cells that are charged in response to these cues ${ }^{[1]}$. The CNS is basically an immunologically favoured site because neuronal information from peripheral immune cells is mostly prevented by the bloodbrain barrier (BBB), a unique structure made up of astrocytes and endothelial cells ${ }^{[2]}$. However, circulating peripheral immune cells might exceed a compromised BBB and encounter neurons and glial cells expressing major histocompatibility complex molecules, perpetuating the immune response ${ }^{[3]}$. Neuroinflammation is usually chronic, as opposed to acute inflammation of the central nervous system [4]. Acute inflammation usually occurs due to damage in the nervous system, featured by inflammatory molecules, tissue edema and platelet deposition, ${ }^{[5]}$, Ramesh ${ }^{[48]}$. Chronic inflammation is the prolonged activation of glial cells and involvement of other immune cells into the brain.

Diabetes mellitus (DM) is marked by increased fasting blood glucose level and polyuria and is a common metabolic disorder. It occurs when there is raised blood sugar level greater than $150 \mathrm{mg} / \mathrm{dL}$ above the normal value of $70-110 \mathrm{mg} / \mathrm{dl}$ in humans [6]. DM occurs due to either lack of insulin, or involvement of factors that counter the activity of insulin [7], Park, Lee, and Chung [49]. Type -2diabetes is increasing in global occurrence and it is vehemently related with obesity and insulin resistance ${ }^{[8]}$, pancreatic $\beta$-cell function. These metabolic disorders hamper the critical regulatory action of insulin on glucose, lipid and protein metabolism $[9,10]$ thus precipitating a disorder exemplified by alterations in these physiological activities ${ }^{[11]}$. Insulin degrading enzyme" (IDE) is a multifunctional enzyme that degrades both insulin related to pathology of T2DM and amylin peptides associated with pathology of neuroinflammation and thus both insulin and amyloid beta competes for this enzyme Bouchern, Kleinridders [47]. IDE is more specific for insulin than for amyloid beta, since brain hyperinsulinemia may deprive amyloid beta of its chief clearing effect facilitating its aggregation in the brain and its eventual neurotoxic influence on the brain ${ }^{[12]}$.

The hippocampus is visible as a segment of gray matter tissue, elevating from the base of each lateral ventricle in the region of the inferior or temporal horn ${ }^{[13]}$. This ridge has an inward fold of the arch cortex into the medial temporal lobe. The 
hippocampus could only be visualized in dissections as it is partly covered by Para hippocampal gyrus. The cortex thins spread from six layers to the three or four layers that represents the hippocampus [14] and the hippocampal structure is used to refer to the hippocampus itself and its associated components [15] as well as the dentate gyrus [16]. The hippocampus, including the dentate gyrus, has the shape of a curved tube, which has been compared to a seahorse, and a ram's horn (Cornu Ammonis). Its abbreviation $\mathrm{CA}$ is used in denoting the hippocampal subfields: CA1, CA2, CA3, and CA4 [17]. It can be differentiated as an area where the cortex narrows into a single layer of heavily compacted pyramidal neurons, which curl into a tight U shape. One edge of the "U," - CA4, is embedded into the backward-facing, flexed dentate gyrus ${ }^{[15,18]}$.

Scientific literature has revealed that hippocampal cognitive effect is critically hinged on steady release of glucose to meet the energy requirements for cognitive processes, and that supply of additional glucose to the hippocampus can improve memory output [19]. Furthermore, findings from in vitro studies have it that insulin can facilitate hippocampal synaptic plasticity i.e. treatment with insulin favours performance on a passive-avoidance memory task and spatial memory training that could alter hippocampal expression of insulin receptor have been investigated ${ }^{[20]}$. An animal model of neuroinflammation has been developed by intracerebroventricular application of STZ. Intracerebroventricular injection of low subdiabetogenic doses of STZ has induced cognitive and brain cholinergic damage ${ }^{[18]}$, oxidative stress as well as reduction in brain glucose/energy metabolic rate and insulin resistant brain state ${ }^{[21]}$. STZ administration has been linked with certain brain morphological changes in the form of astrogliosis found as early as 1 week following the treatment and also extensive cell loss. Oxidative stress has been reported in the first week after treatment with a decreased cholinergic transmission on the hippocampus of STZ-induced intracerebroventricular (ICV) treated rats ${ }^{[22]}$. STZ is a chemical compound extracted from streptomyces achromogenes used to introduce experimental hyperglycemia in mammals. Systemic injection of STZ induces hyperalgesia, frequently associated with hyperglycemia because in some studies, its development was prevented by insulin treatment ${ }^{[23]}$. [24] opined that, although the intraperitoneal administration of $50 \mathrm{mg} / \mathrm{kg} \mathrm{b}$. w. of STZ induced hyperglycemia in $30 \%$ of injected rats, $100 \%$ were down with mechanical hyperalgesia. This observation implied, that, mechanical hyperalgesia is not entirely dependent on STZ-induced hyperglycemia. Its introduction into intracerebroventricular impairs cognitive function by display of glucose metabolic disorder in the brain as well as suppressing the activation of essential enzymes to produce insulin resistance and related processes by lowering the autophosphorylation effect of the insulin receptor [21].

Pioglitazone, a thiazolidinedione (TZD) drug, a class with hypoglycaemic (antihyperglycemic, antidiabetic) action is used in the management of diabetes, (T2DM). Its mode of action facilitates PPAR gamma, the nuclear receptive ability and slightly PPAR-alpha. It lowers liver and peripheral tissue' $s$ ability to resist insulin as well as liver glucose synthesis and reduce glucose content plus blood glycated haemoglobin. It also binds with the outer mitochondrial membrane protein mito NEET with affinity compared to that of PPAR gamma ${ }^{[25]}$. Fibrate are anti-hyperlipidaemic drugs which help elevate HDL but lower blood levels of LDLcholesterol and triglyceride. Studies have demonstrated that it delays progression in diabetes ${ }^{[26]}$ and with insulin resistance; it prolongs progress in the HOMA severity marker ${ }^{[27]}$. Reports have it that, regardless of concurrent use of antidiabetic drugs, fibrate in dyslipidemia with diabetes or hyperglycemia significantly reduce haemoglobin A1c (HbA 1c) concentration ${ }^{[28]}$. This study was therefore, aimed at evaluating the activity of PPRA gamma agonist; pioglitazone and fenofibrate treated insulin resistant rats.

\section{Materials and Methods}

\subsection{Material}

\subsubsection{Drugs and reagents}

STZ was procured from Sigma-Aldrich Company, (USA). HFD was compounded at OgoOluwa feeds, Ilorin, Nigeria. Fenofibrate was 
procured from Bharat Parenteral Ltd, Gujarat, India. Pioglitazone was procured from Micro Labs Ltd, India. Other materials and reagents used were of analytical grades.

\subsubsection{Experimental animals}

Forty-two (42) male rats of $200 \pm 10 \mathrm{~g}$ average weight which was obtained from Temmy Rat Farm, Ogbomosho, Oyo State, Nigeria, was used for the research. Adequate care was given to the animals and ethical clearance was granted by the Ethical Review Committee of University of Ilorin, Nigeria. The animals were allowed to get used to the new environment for a period of 14 days during which they were fed with animal feed and allowed free access to drinking water. The room temperature remained at $23 \pm 5{ }^{\circ} \mathrm{C}$.

\subsection{Methods}

\subsubsection{Preparation HFD}

The rats were fed with high fat feed purchased from Ogo-Oluwa Livestock Sango, Ilorin, Kwara State, Nigeria, as modified by ${ }^{[29]}$. The composition of the modified fat diet is shown in the table below:

Table 1: Component of HFD

\begin{tabular}{|c|c|c|}
\hline Composition & HFD Quantity $(\mathrm{kg})$ & Normal Diet Quantity $(\mathrm{kg})$ \\
\hline Maize & 5.5 & 0.5 \\
\hline Wheat offal & 0.5 & Nil \\
\hline Groundnut Cake & 6.5 & 10 (Processed) \\
\hline Soya Meal & 13.5 (Toasted) & 10 \\
\hline PKC & 5 & 0.5 \\
\hline Bone Meal & 0.5 & 0.5 \\
\hline Fish Meal & 0.5 & 0.015 \\
\hline Methionine & 0.025 & 0.015 \\
\hline Lysine & 0.015 & 0.0825 \\
\hline Industrial Salt & 0.0825 & 0.0425 \\
\hline Broiler Premix & 0.0425 & \\
\hline
\end{tabular}

\subsubsection{Preparation and administration of STZ solution}

STZ was prepared in solution and administered to the experimental animals at $30 \mathrm{mg} / \mathrm{kg}$ body weight for five days consecutively. STZ was administered intraperitoneal in citrate buffered $(0.1$ $\mathrm{M}, \mathrm{pH} 4.5$ ) solution.

\subsubsection{Preparation of sodium citrate buffer}

$1.05 \mathrm{~g}$ citric acid salt and $1.29 \mathrm{~g}$ sodium citrate salt was added to $50 \mathrm{ml}$ distilled water.

\subsubsection{Animal grouping and extract administration}

The experimental animals were placed into seven (7) groups of six (6) rats. This was created based on combination of substances of administration according to the table below: 
Table 2: Animal grouping, treatments, dosage, duration of administration and number of animals per group

\begin{tabular}{|c|c|c|c|c|c|}
\hline $\mathbf{S} / \mathbf{N}$ & Groups & $\begin{array}{l}\text { Substance and route of } \\
\text { administration }\end{array}$ & $\begin{array}{l}\text { Dosage of substance } \\
\text { administered }\end{array}$ & $\begin{array}{l}\text { Duration } \\
\text { administration }\end{array}$ & $\begin{array}{l}\text { No of } \\
\text { animals }\end{array}$ \\
\hline $\mathbf{A}$ & Control & Distilled Water & Ad libitum & 90 days & 6 \\
\hline $\mathbf{B}$ & STZ +HFD & $\begin{array}{l}\text { STZ (intraperitoneal) and } \\
\text { HFD freely }\end{array}$ & $\begin{array}{l}30 \mathrm{mg} / \mathrm{kg} \text { b. w., HFD, } \\
\text { freely }\end{array}$ & $\begin{array}{l}\text { STZ,(5 consecutive days) } \\
\text { and HFD for } 70 \text { days }\end{array}$ & 6 \\
\hline $\mathbf{C}$ & $\begin{array}{l}\text { STZ +HFD+ } \\
\text { Pioglitazone }\end{array}$ & $\begin{array}{l}\text { STZ(intraperitoneal),HFD, } \\
\text { freely and pioglitazone } \\
\text { orally. }\end{array}$ & $\begin{array}{ll}\text { STZ, } 30 \mathrm{mg} / \mathrm{kg} & \mathrm{b} . \mathrm{w} . ; \\
\mathrm{HFD}, & \text { freely; } \\
\text { pioglitazone,10 } \mathrm{mg} / \mathrm{kg} \\
\text { b. w. }\end{array}$ & $\begin{array}{l}\text { STZ,(5 consecutive days), } \\
\text { HFD, } 70 \text { days and } \\
\text { pioglitazone, } 14 \text { days }\end{array}$ & 6 \\
\hline$\overline{\mathbf{D}}$ & $\begin{array}{l}\text { STZ }+ \text { HFD }+ \\
\text { Fenofibrate }\end{array}$ & $\begin{array}{l}\text { STZ (intraperitoneal), } \\
\text { HFD freely and } \\
\text { fenofibrate orally. }\end{array}$ & $\begin{array}{lr}\text { STZ, } 30 & \mathrm{mg} / \mathrm{kg} \mathrm{b} . \\
\text { w.,HFD, } & \text { freely; } \\
\text { fenofibrate, } & 30 \mathrm{mg} / \mathrm{kg} \\
\text { b. w. } & \end{array}$ & $\begin{array}{l}\text { STZ,(5 consecutive days), } \\
\text { HFD, } 70 \text { days and } \\
\text { fenofibrate, } 14 \text { days }\end{array}$ & 6 \\
\hline $\mathbf{E}$ & $\begin{array}{l}\text { STZ+HFD } \\
+ \text { Pioglitazone } \\
+ \text { Fenofibrate }\end{array}$ & $\begin{array}{l}\text { STZ (intraperitoneal), } \\
\text { HFD freely and plus } \\
\text { pioglitazone } \\
\text { fenofibrate orally. }\end{array}$ & 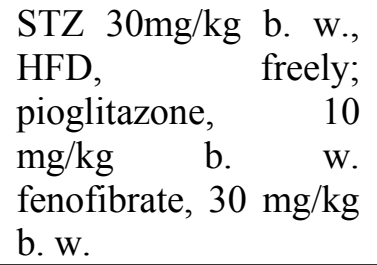 & $\begin{array}{l}\text { STZ,(5 consecutive days), } \\
\text { HFD, } 70 \text { days and } \\
\text { fenofibrate } \\
\text { pioglitazone, } 14 \text { days. }\end{array}$ & 6 \\
\hline $\mathbf{F}$ & $\begin{array}{l}\text { Pioglitazone } \\
\text { only }\end{array}$ & oral & $10 \mathrm{mg} / \mathrm{kg} \mathrm{b.} \mathrm{w.}$ & 14 days. & 6 \\
\hline $\mathbf{G}$ & $\begin{array}{l}\text { Fenofibrate } \\
\text { only }\end{array}$ & Oral & $10 \mathrm{mg} / \mathrm{kg}$ b. w. & 14 days. & 6 \\
\hline
\end{tabular}

STZ = streptozotocin, HFD = high fat diet dosage

Concentration of STZ to administered per rat equal $30 \mathrm{mg} / \mathrm{kg}$ mass $=30 / 1000 \mathrm{mg} / \mathrm{kg}=0.03 \mathrm{mg} / \mathrm{kg}$ body mass for $\times(\mathrm{g})$ of animal:0.03(x)mg of STZ

$200 \mathrm{mg}$ of STZ in $10 \mathrm{ml}$ of buffer therefore $20 \mathrm{mg} \mathrm{STZ}$ gave $1 \mathrm{ml}$ of buffer

Table 3: Volume of STZ administered (ml)

\begin{tabular}{|l|c|c|c|c|c|c|}
\hline \multicolumn{1}{|c|}{ Group } & 1 & 2 & 3 & 4 & 5 & 6 \\
\hline HFD+STZ & 0.414 & 0.357 & 0.444 & 0.42 & 0.42 & 0.447 \\
\hline HDF+STZ+FENO & 0.369 & 0.384 & 0.399 & 0.402 & 0.378 & 0.39 \\
\hline HFD+STZ+PIO & 0.402 & 0.402 & 0.369 & 0.378 & 0.306 & 0.375 \\
\hline HFD+STZ+FENO+PIO & 0.456 & 0.411 & 0.456 & 0.432 & 0.384 & 0.45 \\
\hline
\end{tabular}

\subsubsection{Ethical and animal house approval}

Ethical clearance to use the Animal House was conveyed by the Committee on Ethical Review of

the Faculty of Basic Medical Sciences, University of Ilorin, Kwara State, Nigeria. 
Table 4: Animal grouping and corresponding average weight (g) after acclimatization

\begin{tabular}{|l|l|l|l|l|l|l|}
\hline Group & 1 & 2 & 3 & 4 & 5 & 6 \\
\hline Distilled Water & 226 & 238 & 220 & 168 & 174 & 208 \\
\hline HFD+STZ & 284 & 268 & 270 & 274 & 276 & 270 \\
\hline HFD+STZ+BEZ & 238 & 254 & 234 & 238 & 220 & 254 \\
\hline HFD+STZ+PIO & 272 & 260 & 248 & 238 & 214 & 208 \\
\hline HFD+STZ+BEN+PIO & 256 & 282 & 270 & 258 & 254 & 292 \\
\hline BEZ & 180 & 188 & 190 & 188 & 184 & 168 \\
\hline PIO & 216 & 208 & 202 & 208 & 228 & 188 \\
\hline
\end{tabular}

Table 5: Grouping of animals and their average weight (g) before STZ administration

\begin{tabular}{|l|l|l|l|l|l|l|}
\hline Group & 1 & 2 & 3 & 4 & 5 & 6 \\
\hline Dist. Water & & & & & & \\
\hline HFD+STZ & 276 & 238 & 296 & 280 & 280 & 298 \\
\hline HFD+STZ+BEZ & 246 & 256 & 266 & 268 & 252 & 260 \\
\hline HFD+STZ+PIO & 304 & 274 & 304 & 288 & 256 & 300 \\
\hline HFD+STZ+FENO+PIO & 268 & 268 & 264 & 252 & 204 & 250 \\
\hline BEZ & 174 & 202 & 216 & 200 & 178 & 208 \\
\hline PIO & 228 & 204 & 234 & 216 & 224 & 234 \\
\hline
\end{tabular}

Each soft gelatin capsule of fenofibrate and pioglitazone contains 400mg Tocopheryl Acetate BP and a single dose of $500 \mathrm{mg} / \mathrm{kg} \mathrm{b}$. w. daily was given to rats in group V for a period of 3 weeks using an oral gavage.

\subsubsection{Behavioural assay}

\subsubsection{The Morris water maze assay}

The Morris water maze (MWM) determination involves visible and invisible platform training sessions consisted of 3 days as well as pilot trial on the fourth day which was used to determine the intellectual ability of the rats ${ }^{[30,31]}$. The maze is a spherical pool (100 cm in diameter, $50 \mathrm{~cm}$ in height) which was coated black colour and contained $22 \pm 2{ }^{\circ} \mathrm{C}$ milk water to a depth of $30 \mathrm{~cm}$ with a stage of ( $9 \mathrm{~cm}$ in diameter). It was positioned in a dimly illuminated, sound-free evaluation room. The platform was placed in the middle of the 4 quadrants and remained there throughout the experiment. At days 1-2, each rat was individually trained in both visible-platform and while on day 3 , the hidden-platform training took place. Visible platform training was done for baseline differences in ability to visualize things and quest to get motivated; the platform was positioned $1 \mathrm{~cm}$ below the surface of the water and was denoted by a little flag $(5 \mathrm{~cm}$ in height). The hidden-platform assay determined the spatial intellectual ability and was used to determine the retention of knowledge to find the platform. During the training sessions (days), the platform was submerged $1 \mathrm{~cm}$ below the surface of the water and the flag was taken away. On each day, the rat was made to undertake 4 trials with a 1hour interval between trials. Each trial was duration of 90 seconds unless the animal got to the platform. The test was ended and the rat was carefully positioned to the platform for 30 seconds if a rat failed to locate the platform within 90 seconds. On day 4 , the platform was taken away and the probe trial started, and rats had 90 seconds to locate for the platform. The length of time and path that the rats had spent in the target quadrant, in which the hidden escape platform was previously found, was 
recorded. Also, the times of the rats swimming through the hidden escape platform were also penned using stop watch.

\subsubsection{Euthanasia and sacrifice}

Experimental animals were euthanized using $25 \mathrm{mg} / \mathrm{kg} \mathrm{b}$. w. of ketamine intraperitoneally at the lower left quadrant $24 \mathrm{hrs}$ after the last day of administration. Incision was made from the lower abdominal cavity to the thoracic cavity. The animals were perfused with $4 \%$ buffered paraformaldehyde and the brain was careful harvested with the hippocampi removed and fixed immediately in 4\% buffered paraformaldehyde. Whole blood was taken from the right ventricle of heart of the experimental animals before perfusion, and used for biochemical studies.

Incision was made from the anterior abdominal wall of the animal to the thoracic cavity to expose the heart. Prior to perfusion, blood samples were taken by piercing the right ventricle of the heart with a needle fitted to a $5 \mathrm{ml}$ syringe, and the blood was collected into heparinized bottles and kept for biochemical studies. The brains were also harvested from individual rat and rinsed with sucrose solution. The hippocampus was dissected, weighed, homogenized [using $50 \mathrm{mM}$ phosphate buffered saline (PBS) of $\mathrm{pH} 7.0$ containing $0.1 \mathrm{mmol} / \mathrm{L}$ ethylenediaminetetraacetic acid (EDTA)] and homogenate centrifuged at $3000 \times \mathrm{g}$ for $15 \mathrm{~min}$ at $3{ }^{\circ} \mathrm{C}$. The supernatant obtained was used to assay for T-AOC, superoxide dismutase, catalase, glutathione peroxidase, reduced glutathione, thiobarbituric acid reactive substances, $\mathrm{ACh}$, and AChE assays.

The cortex was processed via fixation, dehydration, clearing, infiltration, embedding, sectioning and staining. Tissue fixing was carried out in $10 \%$ formalin to avoid tissue digestion by bacteria or available enzymes within the cells (autolysis) to maintain the biological activities and thereafter transferred to $50 \%, 70 \%, 90 \%$ charge of absolute alcohol for 45 minutes each so that the water was extracted by bathing them in gradual series of alcohol and water. Tissue clearing was carried out in xylene to replace ethanol with a solvent miscible with embedding medium. Tissue staining was achieved with haematoxylin and eosin (H \& E) followed by special stains like Bielschowsky's silver stain and GFAB immunostaining to detect the neuronal change.

\subsubsection{Data presentation and analysis}

Findings were presented as the mean of six replicates \pm SEM. Statistical difference was obtained by ANOVA and Duncan's Multiple Range Test at 5\% level of confidence using SPSS 20.0 package.

\section{Results}

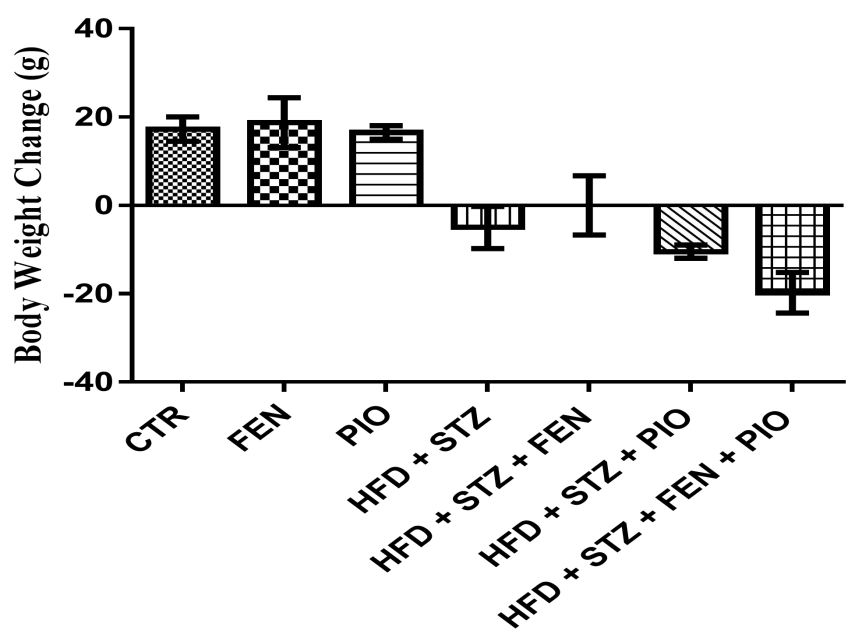

Figure 1(a): Body weight difference before and after treatments of Wistar rats across all the groups. There was significant $(\mathbf{P}<\mathbf{0 . 0 5})$ decrease in weight of the animal's body in all the treatment groups (treated and untreated) at the end of the experiment (Figure 1a) 


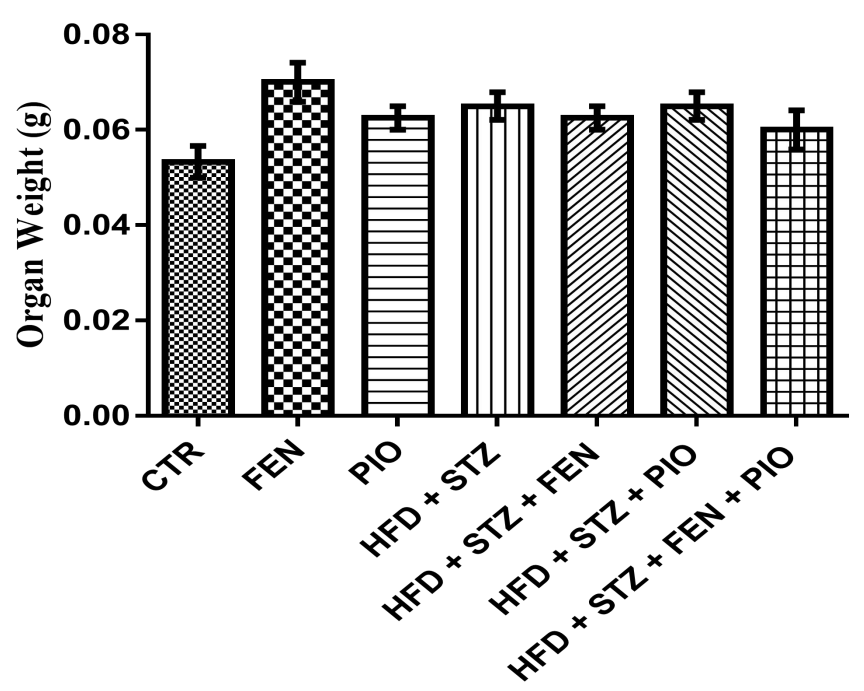

Figure 3.1(b): Organ-to-body weights ratio of Wistar rats across the groups. There is no significant $(P>0.05)$ difference in the relative organ weight of rats when compared across the groups $(\mathrm{P}<0.05)$ (Figure 3.1b)

\subsection{Studies}

Moris water maze test

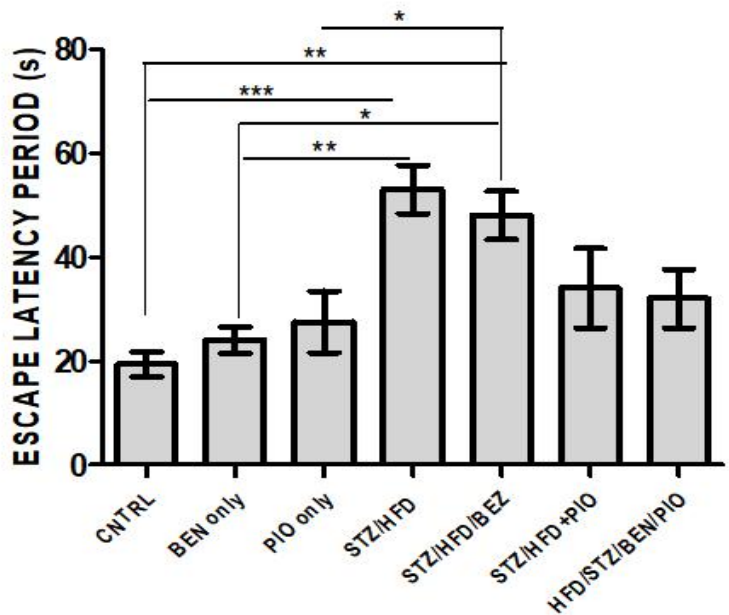

Figure 3.2: Graph of Moris water maze test across the groups. The treated groups showed substantively $(P<0.05)$ lowered memory in comparison with the control group and notably $(\mathrm{P}<0.05)$ improved memory when weighed up with the untreated group animals (Figure 3.2)

\subsection{Glucose-6-phoshate dehydrogenase}

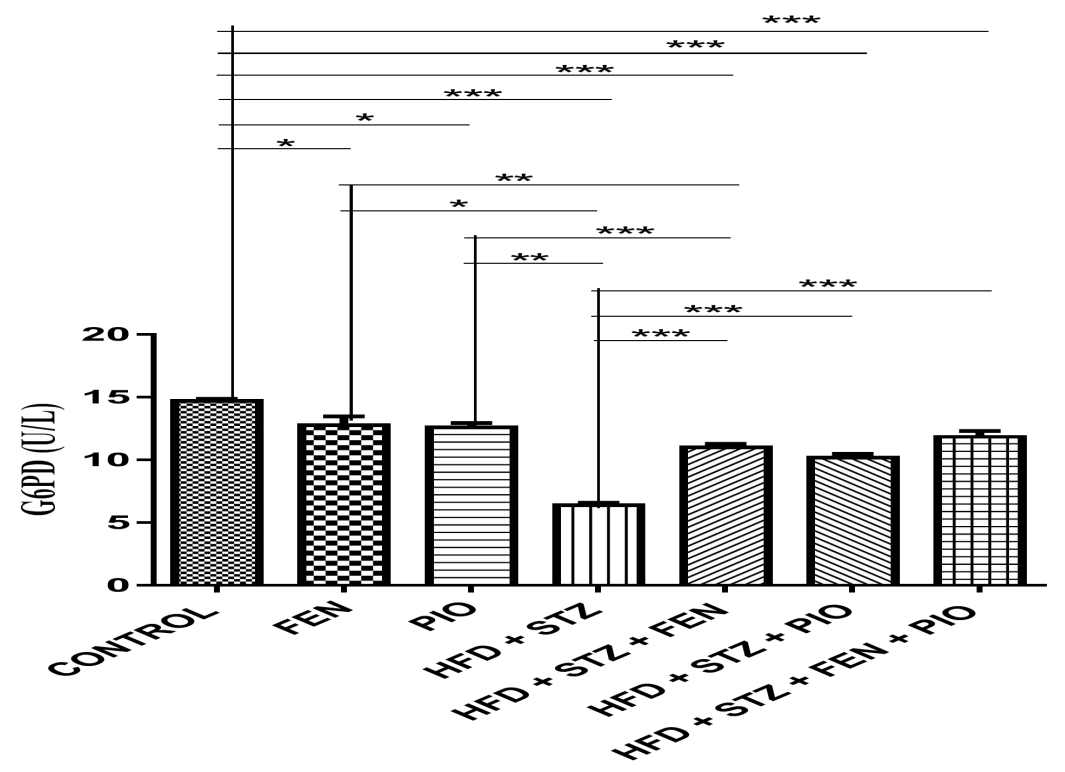

Figure 3.3: G6PD levels in the rats' hippocampi

The treated groups showed substantively $(\mathrm{P}<0.05)$ lowered the activity of glucose-6-phosphate dehydrogenase in relation with the normal control group animals and a notably $(P<0.05)$ higher G6PD activity when leveled up with the untreated group animals (Figure 3.3) 
Histological Changes
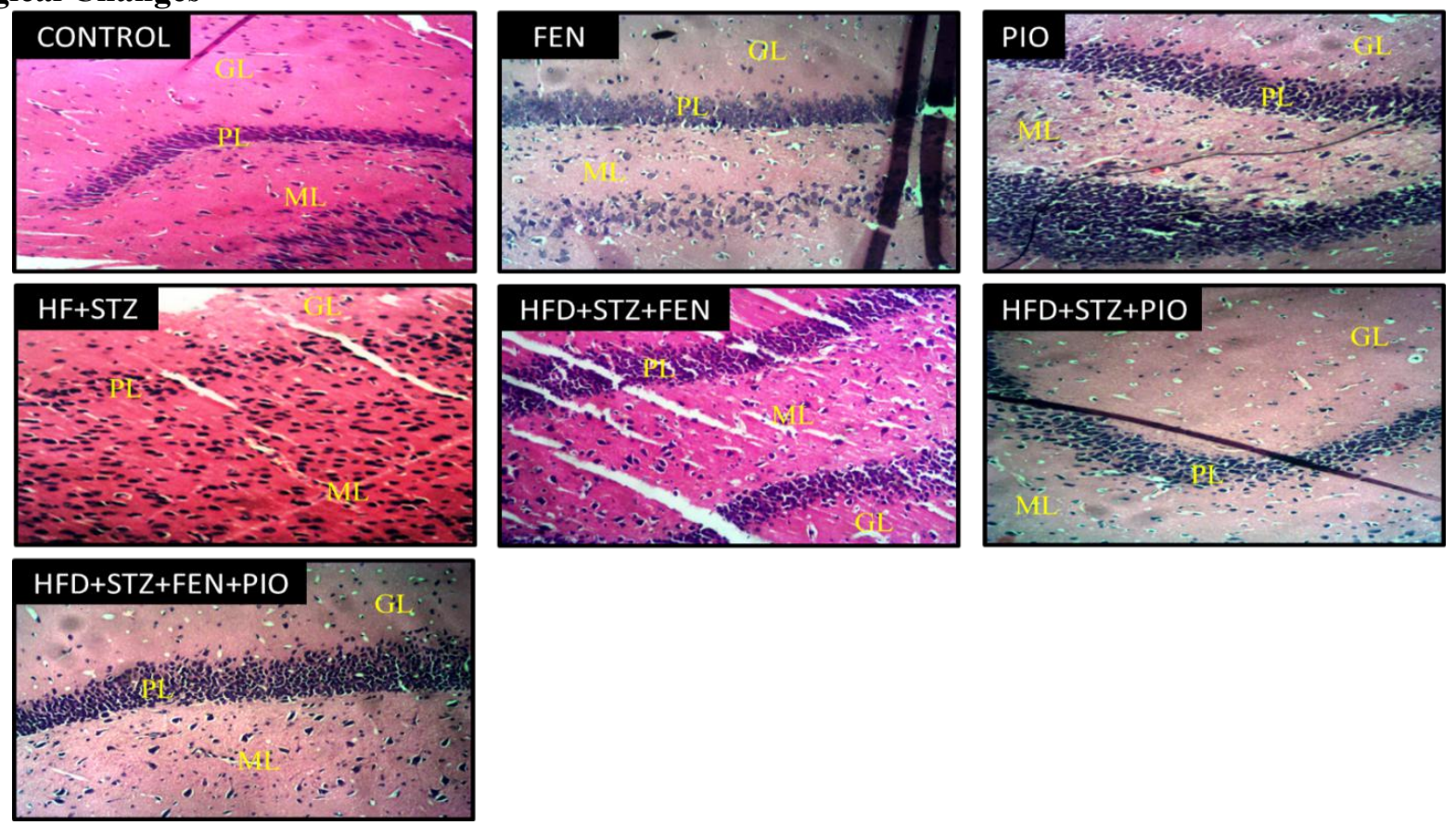

Plate 1: Haematoxylin and eosin staining of the hippocampus (magnification: $x 100$ ) which revealed the overall morphology of hippocampus of white rats. GL: granular layer, PL: pyramidal layer, ML: molecular layer
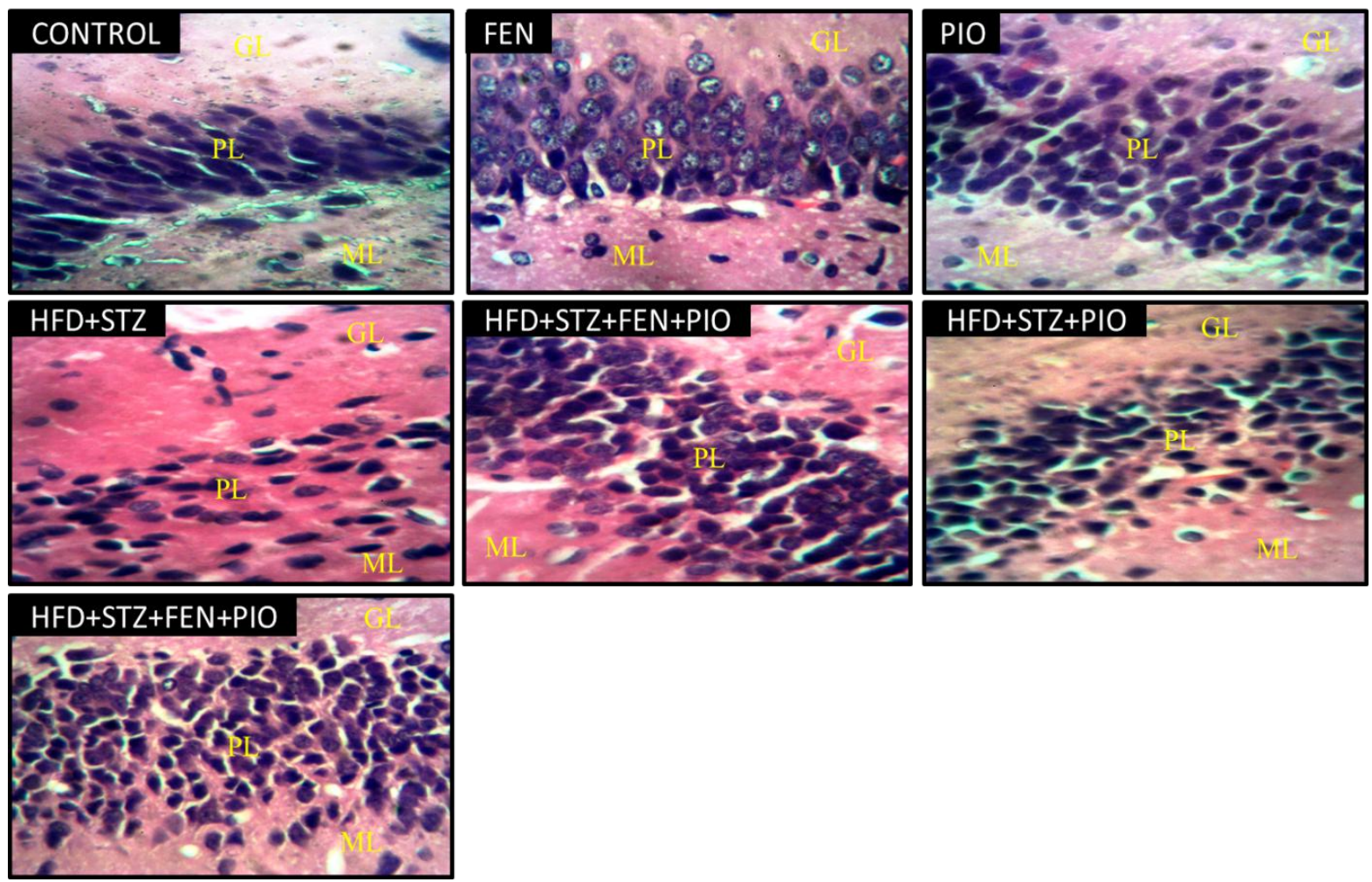

Plate 2: Haematoxylin and eosin staining of the hippocampus (magnification: $x 400$ ) which displays the entire histoarchitecture of hippocampus of albino rats. GL: granular layer, PL: pyramidal layer, ML: molecular layer 

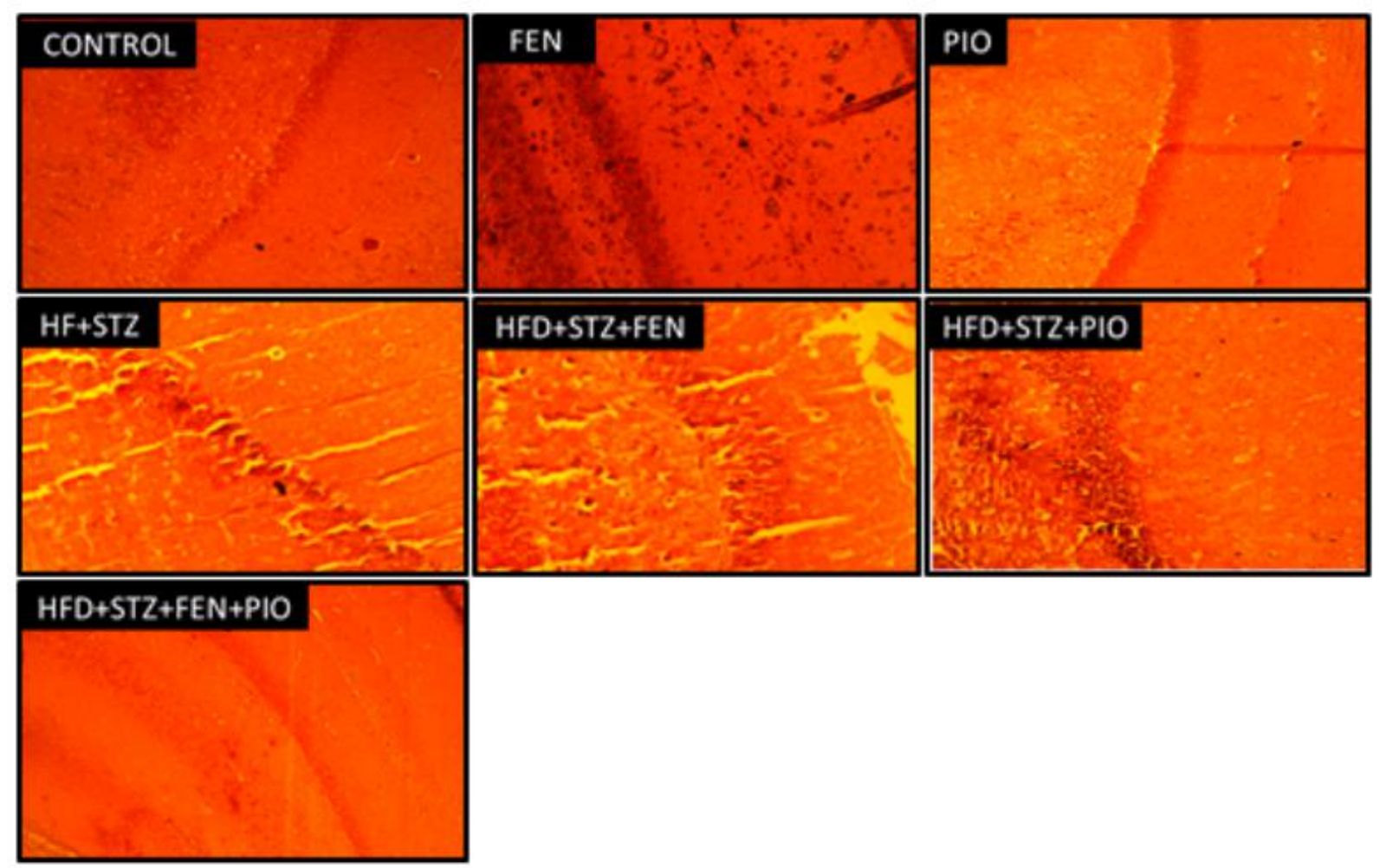

Plate 3: Belchowsky stain of the hippocampus (magnification: x100) showing the axonal process of the hippocampus of Wistar rats

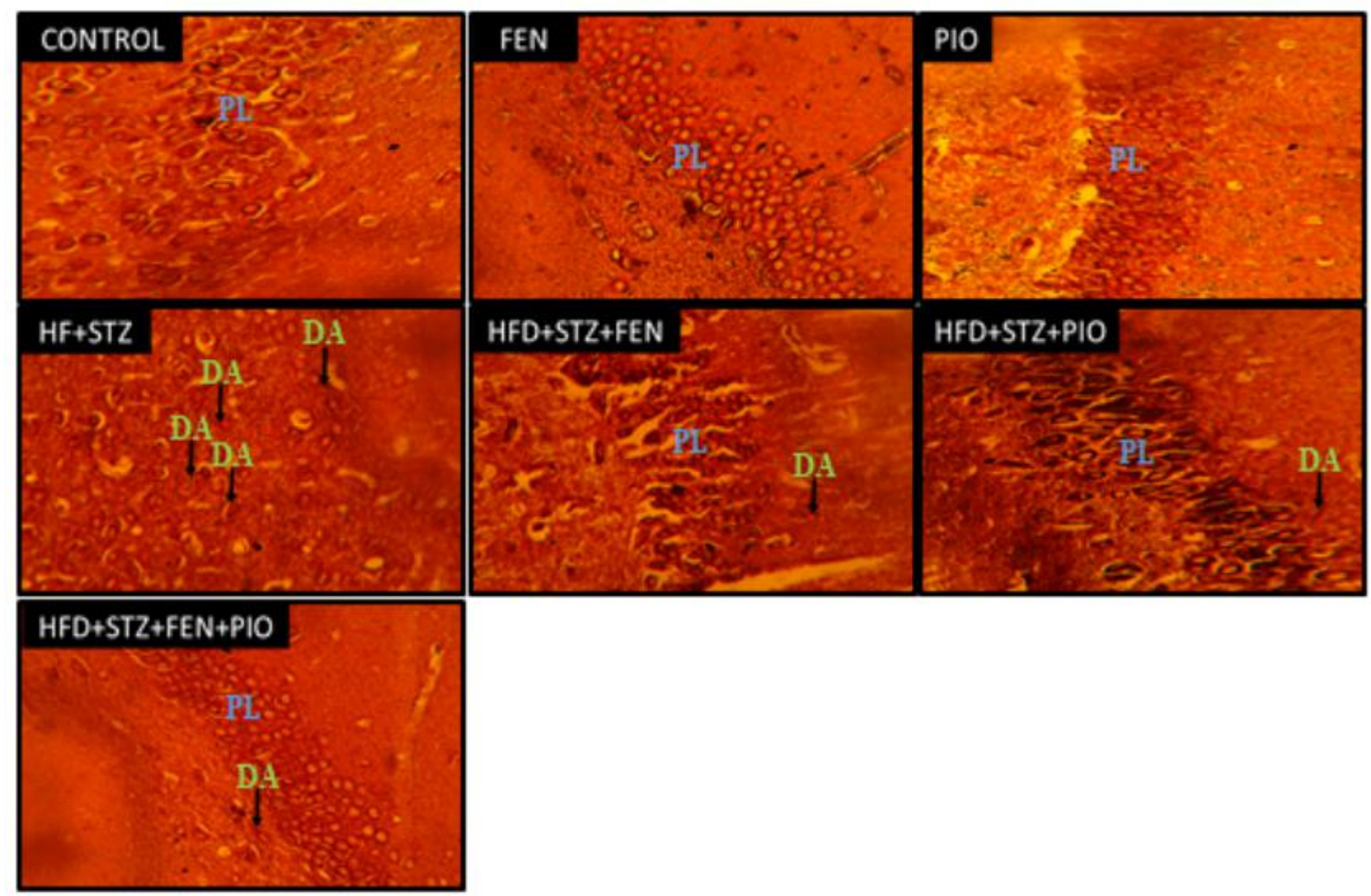

Plate 4: Belchowsky stain of the hippocampus (magnification: $x 400$ ) showing the axonal process of the hippocampus of Wistar rats. DA: Degenerative axon, PL: pyramidal layer 

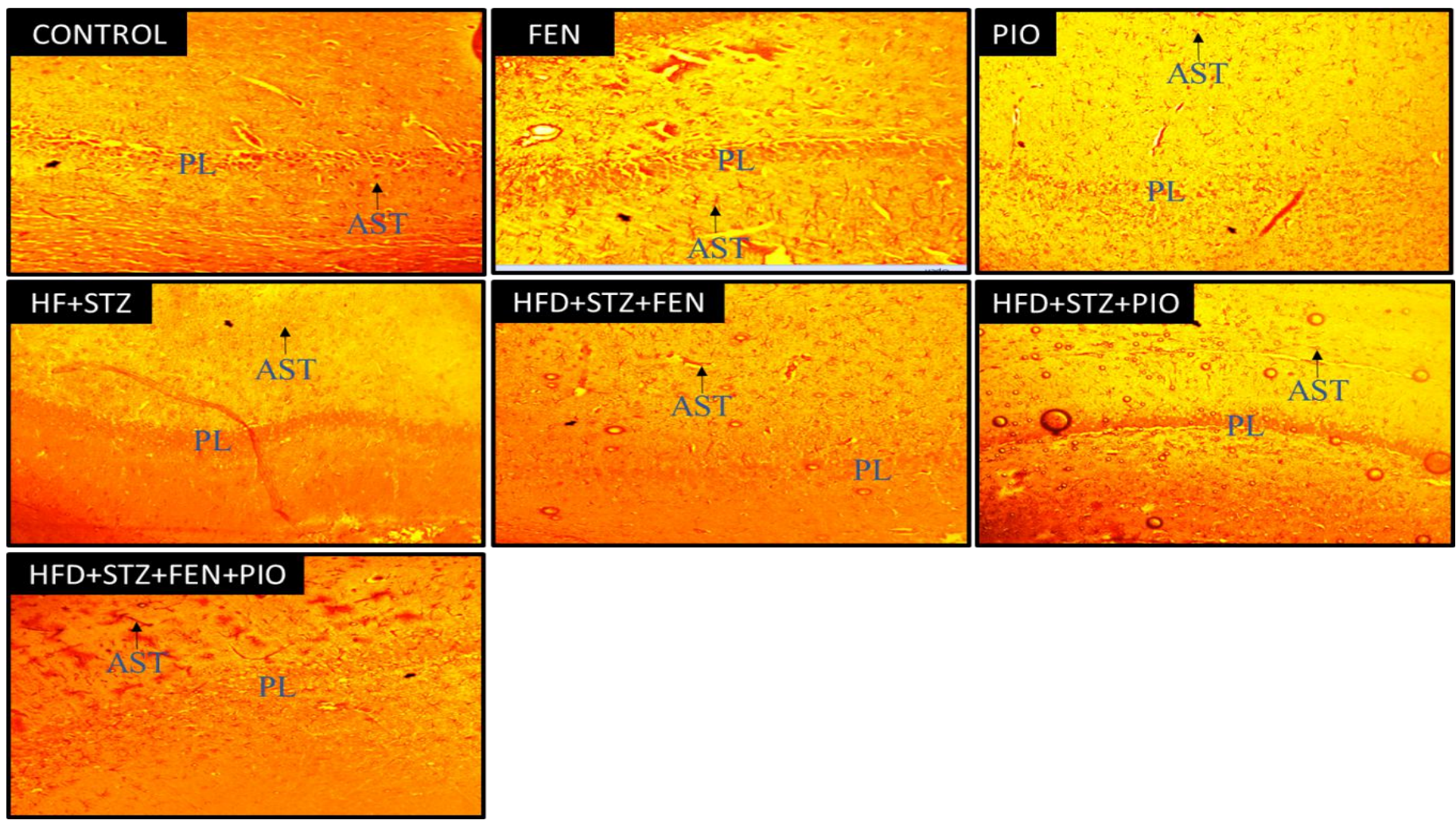

Plate 5: GFAP immunostaining of the hippocampus of Wistar rats for astrocytes activation (Magnification: x100). PL: Pyramidal layer, AST: Astrocyte
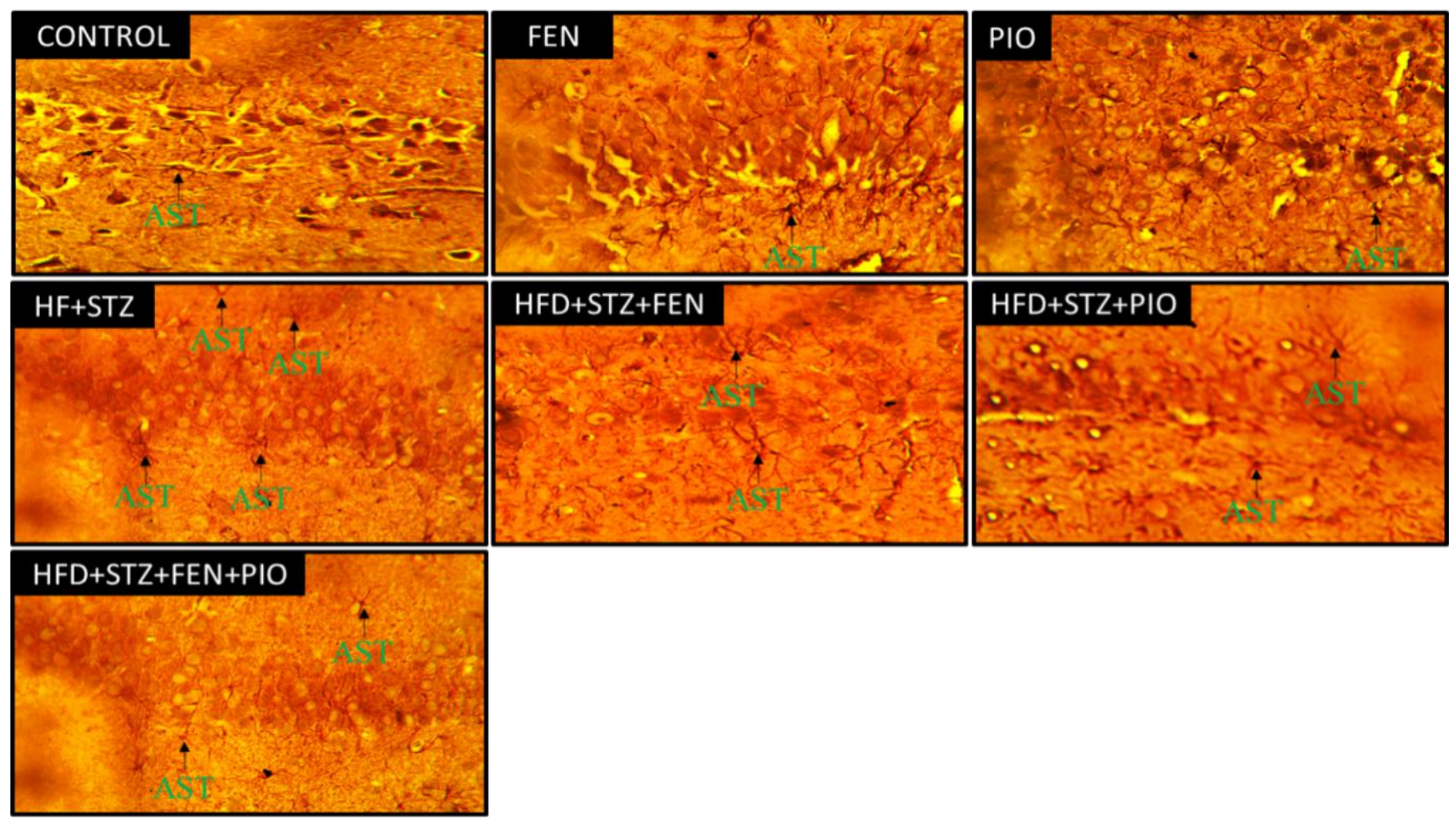

Plate 6: GFAP immunostaining of the hippocampus of Wistar rats for astrocytes activation (Magnification: $\mathbf{x 4 0 0 )}$. The astrocytes are more expressed in the treated groups compared to the control and less expressed compared to the test group. PL: Pyramidal layer, AST: Astrocy 


\subsection{Fasting Blood Glucose}

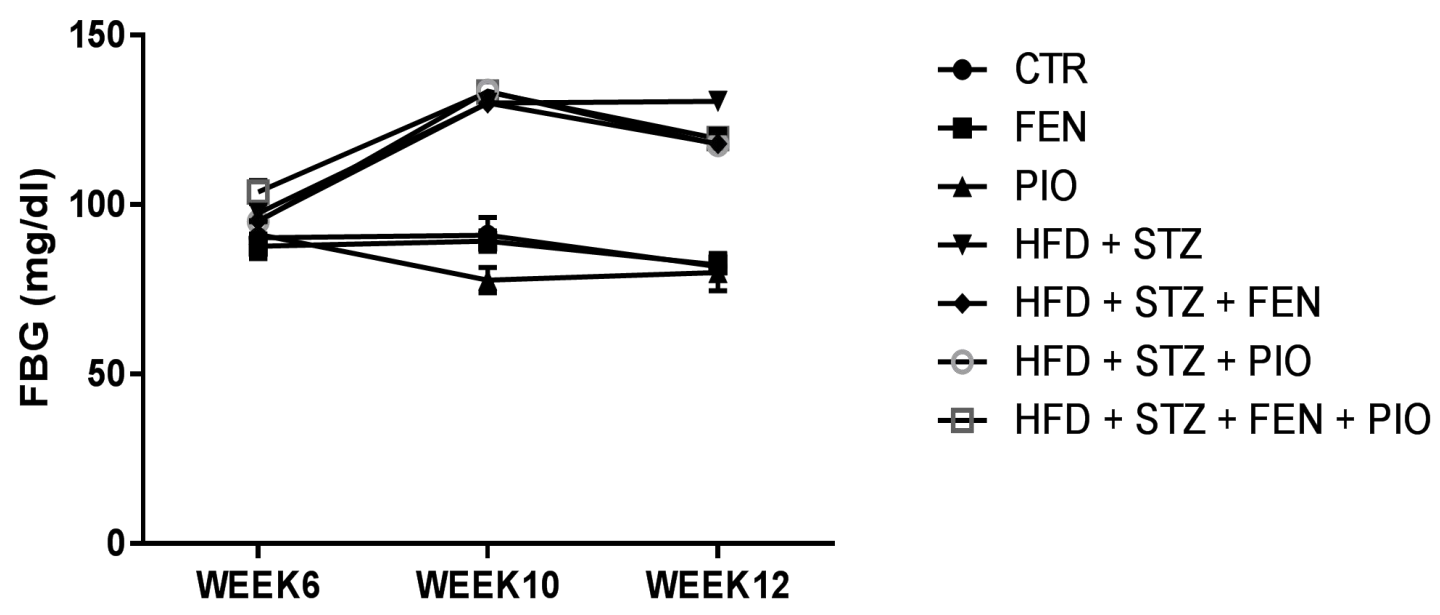

Figure 3.4: Fasting blood glucose levels across all groups after sacrifice. Week 6: just before the administration of STZ, week 10: just before the commencement of treatment, week 12: after two weeks of treatment. At four weeks after co-administration of HFD and STZ (end of week 10) the blood glucose of the animals in the test groups increased appreciably $(\mathrm{P}<0.05)$ compared to the control group. After two weeks of treatment (end of week 12), the treated groups showed sufficiently $(P<0.05)$ lowered blood glucose levels when set side by side with the untreated animals but remained remarkably $(\mathrm{P}<0.05)$ higher than the distilled water treated control animal

\subsection{Fasting Plasma Glucose}

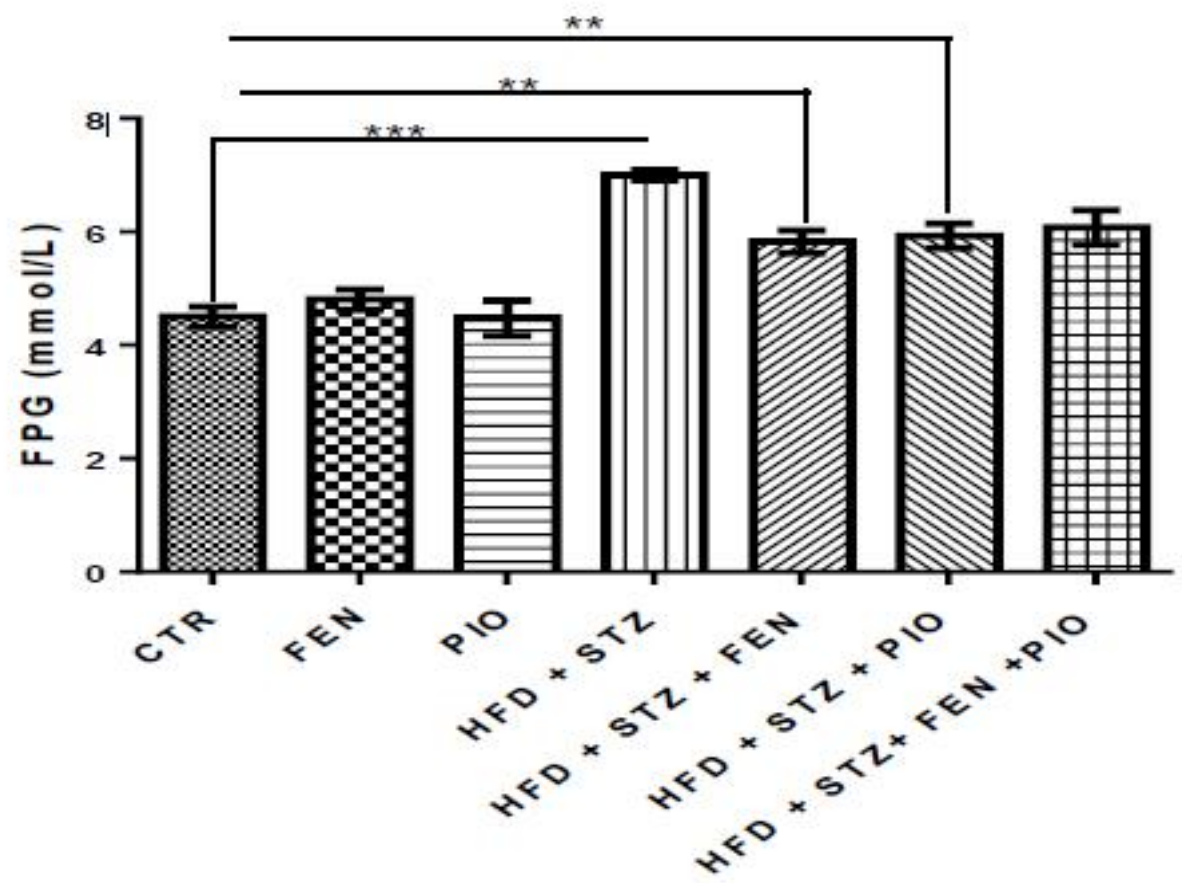

Figure 3.5: Fasting plasma sugar concentration across the entire groups after sacrifice. * $(P<0.05)$ There was substantive $(P<0.05)$ increase in the treatment groups when liken with the normal control animals. The whole treatment groups displayed glaring $(\mathrm{P}<0.05)$ decrease when related with the untreated group animals and meaningfully $(\mathrm{P}<0.05)$ higher levels than animals in the control 


\subsection{Fasting Plasma Insulin}

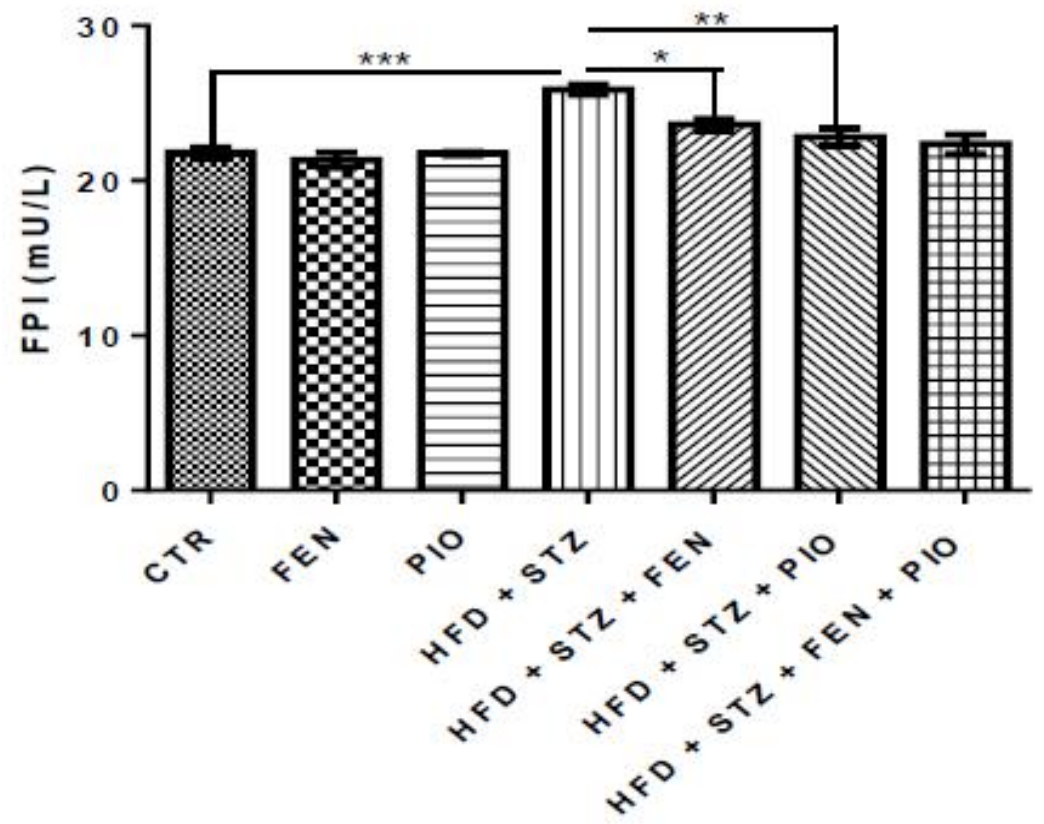

Figure 3.6: Shows fasting serum insulin levels in animals across all groups after sacrifice. There was exceptional $(P<0.05)$ increase in the treatment group animals when juxtaposed with the distilled water treated control group animals. The entire animals in the treatment groups revealed notable $(P<0.05)$ decrease in comparison with animals in the untreated set and substantively $(\mathbf{P}<0.05)$ higher levels than those of the control group animals

\subsection{Homeostatic Mode of Assessing Resistance to Insulin (HOMA-IR)}

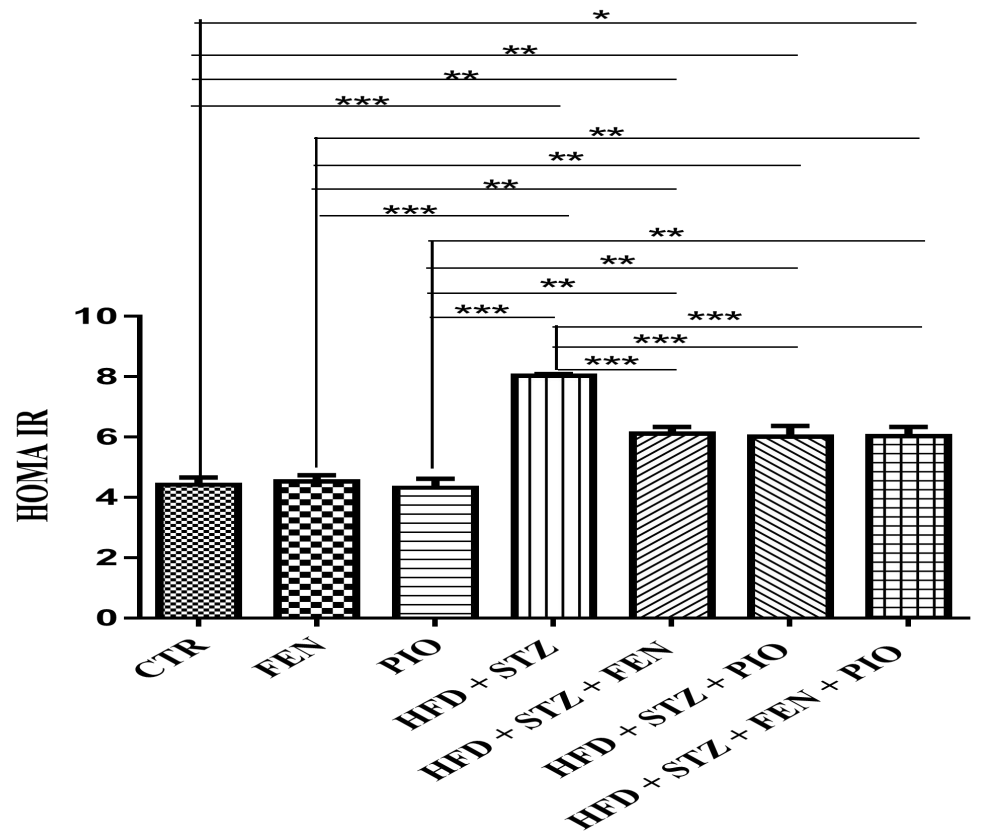

Figure 3.7: Graph of HOMA-IR to check for insulin resistance in the animals across all the groups *(P<0.05) 


\section{Discussion}

Peroxisome proliferating-activated receptor gamma (PPAR- $\gamma$ or PPARG), the receptor specific for glitazone, or NR1C3 (nuclear receptive subfamily 1, group C, member 3 ) is a type II nuclear receptor found among humans where it is coded by the PPARG gene ${ }^{[32]}$. PPARG regulates fatty acid storage and glucose metabolism. The genes activated by PPARG stimulate lipid uptake and adipogenesis by fat cells. PPARG knockout mice fail to generate adipose tissue when fed a high-fat diet ${ }^{[33]}$.

The decrease in weight of the rat's body in the groups to which HFD and STZ was administered may an indication of imbalance in glucose homeostasis and muscle weakness due to excessive breakdown in tissue protein ${ }^{[34]}$.

A meaningful decrease in the value of organto-body weight ratio can be traced to organ necrosis, while a meaningful increase in value is a potential sign of tissue inflammation ${ }^{[35]}$. The absence of substantive difference in organ-to-body weight ratio of the organs (hippocampi) across the groups may imply maintenance in organ structure. Experimental findings have it that there is connection between issues of insulin insensitivity and resistance to insulin (IR) as well as cognitive malfunction; however there are sufficient variations in our knowledge of the mode of action responsible for this relationship [36]. Animal employed in IR processes help bridge these spaces pointing to hippocampal IR as a possible mediator of cognitive malfunction in T2DM ${ }^{[37]}$.

The lowered memory output in the treated set of animals following behavioral test using Moris water maze when liken with the distilled water control group animals, in the present study, may imply memory/learning impairment induced by oxidative stress $^{[38,39]}$.

A number of assay indices have been suggested which includes lipid peroxides, malondialdehyde, and 4-hydroxynonenal as possible parameters that could generate free radicals thereby causing oxidative damage to lipids. Isoprostan is generated from free radical oxidation of arachidonic acid; 8-oxoguanine (8hydroxyguanine) and thymineglycol as pointers of oxidative issues that affect DNA; as well as several outputs of the oxidation of protein and amino acids including carbonyl protein, hydroxyleucine, hydrovaline, and nitrotyrosine ${ }^{[50]}$. The appreciable reduction in activity of G6PD in animals that received with HFD and STZ when matched up with animals in the control group may be due to ability of HFD and STZ to mediate decrease in enzyme production in vivo.

Tissue histolopathological analysis may be employed as complementary evidence to analysis on function indices and enzymic assays by showing any disruption to normal histoarchitectural arrangement of the tissues [40]. Neuronal degeneration or cellular damage in neurons have been reported to result in cell death ${ }^{[41]}$. Histological examination which showed no expression of degenerative axon process as well as normal hippocampus architecture of three layers (granular, pyramidal and molecular layers) in the control group is an indication of maintenance of the histoarchitecture of the hippocampus. The nondisplay of degenerative axon in hippocampus of the control group animals may be due to a defense mechanism exerted by the brain cells ${ }^{[42]}$. The mild to severe expression of degenerative axonal process of the brain in the test group may be an indication of derangement and/or neuronal degeneration on the hippocampus which would have consequential effect on histoarchitecture of brain cells ${ }^{[43,44]}$.

The raised level of blood glucose following coadministration of HFD and STZ for four weeks when matched up with the control group may be due to HFD and STZ ability to lower insulin sensitivity. The improvement in blood level after two weeks of treatment in comparison with the untreated animals may imply a boost in glucose uptake facilitated by enhanced insulin sensitivity.

The reduction in concentration of blood glucose of animals in the treatment groups in comparison with those of the untreated set may be an indication of improvement in glucose usage by tissues for their energy requirements or accelerated insulin generation by $\beta$-cells of the pancreas $[45,46]$. Insulin produced by the pancreas during periods of insulin resistance are resistant to the biological system and they are unable to effectively use them, causing hyperglycaemia. Beta cells of the pancreas therefore increase their insulin productive capacity leading to hyperinsulinemia. This could go 
unnoticed causing type 2 diabetes or latent autoimmune diabetes of adults ${ }^{[14]}$. All the test groups (treated and untreated) exhibit insulin resistance, but the treated groups are significantly less resistant compared to the untreated group.

\section{Conclusion}

This research reveals that PPAR agonism improves hippocampal degenerative condition in HFD and STZ - induced insulin resistant rats as evident in the body weight, organ to body ratio, memory score, histoarchitectural modifications, immunohistological changes, oxidative stress level, fasting blood glucose, as well as fasting plasma glucose and insulin concentrations. A new modality of insulin resistance management was created from PPAR agonist without the necessity of combination with other PPAR agonist types.

\section{Conflict of Interest}

All authors declared that no conflict of interest exist with regard to the research, authorship, and/or publication of this article.

\section{Acknowledgement}

We are grateful to the Department of Physiology, University of Ilorin, and the Department of Biological Sciences, Federal University, Wukari, Nigeria, for their immense contributions towards successful completion of this research study.

\section{References}

1 Janeway Jr CA, Medzhitov R. Innate immune recognition. Annu Rev Immunol 2002;20:197216. Epub 2001. DOI: 10.1146/annurev.immunol.20.083001.084359

2 Sarma P, Grant P, Pant HC. Cyclin-dependent protein kinase $5(\mathrm{Cdk} 5)$ and the regulation of neurofilament metabolism. Eur. J. Biochem 2001;268:1534-1546. DOI: https://www.10.1046/j.1432$\underline{1327.2001 .02025 . \mathrm{x}}$
3 Gostner JM, Becker K, Fuchs D, Sucher R. Redox regulation of the immune response. Redox Rep 2013;18(3):88-94. DOI:www.doi: 10.1179/1351000213Y.0000000044

4 Streit WJ, Mrak RE, Griffin WST. Microglia and neuroinflammation: A pathological perspective. J Neuroinflammation 2004; 1: 14. DOI: https://www. doi:10.1186/1742-2094-1$\underline{14}$

5 Mayer C. Mitochondrial membrane protein stabilized by pioglitazone". Proc. Natl. Acad.

Sci 2013; 104 (36); 14342-7.DOI: https://www.ncbi.nlm.nih.gov/pmc/articles/PM C3477874/

6 Barbagallo M, Dominguez LJ. Type 2 diabetes mellitus and Alzheimer's disease. World J

diabetes 2014: 5(6): 889-893 DOI: $10.4239 /$ wjd.v5.i6.889

7 Ghosh R, Sharatchandra KH, Rita S, Thokchom IS. Hypoglycemic activity of Ficus hispida (bark) in normal and diabetic albino rats. Indian Journal of Pharmacology 2004;

36: 222-225 DOI: http://www.ijponline.com/text.asp?2004/36/4/222/11146

8 Akindele OA, Babatunde AI, Chiedu FM, Samuel AO, Oluwasola LA, Oluseyi AA. Rat model of food induced non obese type 2 diabetes mellitus: comparative pathophysiology and histopathology. Int $\boldsymbol{J}$ Physiol Pathophysiol Pharmacol 2012; 4(1):51-58. PMID:22461957 PMCID:pmc3312463

9 Shoelson SE, Lee J, Goldfine AB. Inflammation and insulin resistance. $\boldsymbol{J}$ Clin Invest $2006 \quad ; \quad 116(7)$ : 1793-1801. DOI: $10.1172 / \mathrm{JCI} 29069$

10 Chen L, Chen R, Wang H, Liang F. Mechanisms Linking Inflammation to Insulin Resistance. International Journal of Endocrinology 2015, Article ID 508409, 9 pages.DOI:http://dx.doi.org/10.1155/2015/508 $\underline{409}$

11 Butler AE, Janson J, Bonner-Weir S. Beta-cell deficit and increased beta-cell apoptosis in humans with type 2 diabetes. Diabetes 2003; 52: 102-110. DOI:10.2337/diabetes.52.1.102

12 Craft S, Watson CS. Insulin and neurodegenerative disease: shared and specific mechanisms. Lancet Neurol 2004; 3: 169-178. 
DOI:10.1016/S1474-4422(04)00681-7

13 Aboitiz F, Morales D, Montiel J. "The evolutionary origin of the mammalian isocortex: towards an integrated developmental and functional approach". The Behavioral and Brain Sciences 2003; 26(5): 535-52

DOI:https://www.ncbi.nlm.nih.gov/pubmed/15 179935

14 Chiu HK, Tsai EC, Juneja R. Equivalent insulin resistance. Diabetes Research and Clinical Practice 2007; 77: 237-44. DOI:10.1016/j.diabres.2006.12.013

15 Best PJ, White AM. Placing hippocampal single-unit studies in a historical context.

Hippocampus 1999; 9(4): 346-51.

DOI: $10.1002 /($ SICI $) 1098-$

1063(1999)9:4<346::AID-HIPO2>3.0.CO;2-3

16 Snell, RS. Clinical Neuroanatomy. 6th ed. Baltimore: Lippincott Williams \& Wilkins.

2006; $469-$

497.https://patientfocus.files.wordpress.com/20 $\underline{12 / 08 / \text { snell-clinical-neuroanatomy-7th- }}$ edition 41.pdf

17 Cho RY, Gilbert A, Lewis DA. "Ch 22. The neurobiology of schizophrenia". In Charney DS, Nestler EJ (eds.). Neurobiology of Mental Illness. 2005. ISBN 978-0-19-518980-3.

18 Mayer C. Traumatic Brain Injury, Neuroinflammation, and Post-Traumatic Headaches.Headaches Current 2018; 12(3):142-9.DOI: $10.1111 /$ head.12173

19 Gold PE. Glucose and age-related changes in memory. Neurobiol Aging 2005; 26 Suppl 1(8):60-4. DOI: 10.1016/j.neurobiolaging.2005.09.002

20 Zhao S, Chu Y, Zhang C. Diet-induced central obesity and insulin resistance in rabbits. Journal of Animal Physiology and Animal Nutrient 2004; 92(1): 105-111.DOI: 10.1111/j.1439-0396.2007.00723.x

21 Verdile, G, Keane, KN, Cruzat, VF, Medic S, Sabale M, Rowles J, Wijesekara N, Martins RN, Fraser PE, Newsholme P. Inflammation and Oxidative Stress: The Molecular Connectivity between Insulin Resistance, Obesity, and Alzheimer's Disease. Mediators Inflamm 2015; 105828. DOI: $\underline{10.1155 / 2015 / 105828}$
22 Ishrat $\mathrm{T}$, Khan MB, Hoda MN, Yousuf $\mathrm{S}$, Ahmad M, Ansari MA, Ahmad AS, Islam F. Coenzyme Q10 modulates cognitive impairment against intracerebroventricular injection of streptozotocin in rats. Behav Brain Res 2006:171:9-16.

DOI: $10.1016 /$ j.bbr.2006.03.009

23 Calcutt NA. Future treatments for diabetic neuropathy: clues from experimental neuropathy. Curr Diab Rep 2002; 2: 482-488. DOI: $10.1007 / \mathrm{s} 00125-004-1354-2$

24 Lee YS, Eun HS, Kim SY, Jeong JM, Seo W, Byun JS, Jeong W, Yi HS. Hepatic immunophenotyping for streptozotocininduced hyperglycemia in mice. Sci Rep 2016; 6: 30656. DOI: 10.1038/srep30656

25 Paddock ML, Wiley SE, Axelrod HL, Cohen AE, Roy M, Abresch EC, Capraro D, Murphy $\mathrm{AN}$. "MitoNEET is a uniquely folded $2 \mathrm{Fe} 2 \mathrm{~S}$ outer in brain neuroscience. Neuroscience 2007; 34(7):154-9.

https://www.ncbi.nlm.nih.gov/pmc/articles/PM C1963346/

26 Tenenbaum A, Fisman EZ, Boyko V, Benderly M, Tanne D, Haim M, Matas Z, Motro M, Behar S. Attenuation of progression of insulin resistance in patients with coronary artery disease by bezafibrate. Archives of Internal Medicine 2006; 166(7): 737-41.

DOI: $10.1001 /$ archinte.166.7.737

27 Tenenbaum A, Motro M, Fisman EZ. Dual and Pan-Peroxisome Proliferator- Activated

Receptors (PPAR) co-agonism: The bezafibrate lessons. Cardiovasc Diabetol 2005;4:14. DOI:10.1186/1475-2840-4-14

28 Teramoto T, Shirai K, Daida H, Yamada N. Effects of bezafibrate on lipid and glucose metabolism in dyslipidemic patients with diabetes: the J-BENEFIT study. Cardiovasc Diabetol 2012 ; 11: 29.DOI:10.1186/14752840-11-29

29 Ayanlere AO, Muhammad-Lawal A, Ayanlere AF. Determinants of household decision to use improved seeds in cereals production in Kwara State, Nigeria. Nigerian Journal of Agriculture, Food and Environment 2015; 11(3):136-

140.DOI:10.3923/pjn.2009.1235.1239 
30 Morris R. Developments of a water-maze procedure for studying spatial learning in the rat. J Neurosci Methods 1984; 11(1):47-60.

DOI:https://www.ncbi.nlm.nih.gov/pubmed/64 71907

31 McDonald RJ, White NM. Parallel information processing in the water maze: evidence for independent memory systems involving dorsal striatum and hippocampus. Behav Neural Biol 2004; 61(3): 260-270.

32 Greene ME, Blumberg B, McBride OW, Yi HF, Kronquist K, Kwan K, Hsieh L, Greene $\mathrm{G}$, Nimer SD. "Isolation of the human peroxisome proliferator activated receptor gamma cDNA: expression in hematopoietic cells and chromosomal mapping".Gene Expr 1995; 4 (4-5): 281-99. DOI: https://www.ncbi.nlm.nih.gov/pubmed/778741 $\underline{9}$

33 Jones JR, Barrick C, Kim KA, Lindner J, Blondeau B, Fujimoto Y, Shiota M, Kesterson RA, Kahn BB, Magnuson MA. Deletion of PPAR $\gamma$ in adipose tissues of mice protects against high fat diet-induced obesity and insulin resistance. Proc. Natl. Acad. Sci 2005; 102(17): $\quad$ 6207-12. DOI: $10.1073 /$ pnas. 0306743102

34 Johnson OJ, Isaac SL, Michael OO, Akintayo $\mathrm{CO}$, Samuel S. Biochemical evaluation of lima beans (Phaseolus lunatus) in alloxaninduced diabetic rats. ARPN Journal of Agriculture and Biological Sciences 2013; 8(4):302-

309.DOI:https://www.researchgate.net/profile/ Rotimi_Ojo5/publication/325654423_ARPN_J ournal_of_Agricultural_and_Biological_Scien ce/links/5b1ade590f7e9b68b429e059/ARPN-

Journal-of-Agricultural-and-BiologicalScience.pdf

35 Chen L, Huidan H, Cui H, Fang J, Zuo Z, Deng J, Li Y, Wang X, Zhao L. Inflammatory responses and inflammation-associated diseases in organs. Oncotarget $\quad 2018 ; 9(6)$ : 7204-7218.DOI: 10.18632/oncotarget.23208

36 Hofmann SM, Tschop MH. Dietary sugars: A fat difference. $J$ Clin Invest 2009;119(5):1089-1092.DOI:

$\underline{10.1172 / \text { jci39332 }}$
37 Rivera-Ramirez F, Escalona-Cardoso GN, Garduno-Siciliano L, Galaviz-Hernandez C, Paniagua-Castro N. Antiobesity and Hypoglycaemic Effects of Aqueous Extract of Ibervillea sonorae in Mice Fed a High-Fat Diet with Fructose. J Biomed Biotechnol 2011; 23(3):431-437. DOI: $10.1155 / 2011 / 968984$

38 Acosta S, Jernberg J, Sanberg CD, Sanberg PR, Small BJ. NT-020, a natural therapeutic approach to optimize spatial memory performance and increase neural progenitor cell proliferation and decrease inflammation in the aged rat. Rejuvenation Res 2010; 13(5):581-588. doi: 10.1089/rej.2009.1011

39 Ekong MB, Ekpene UU, Thompson FE, Peter AI, Udoh NB. Effects of co- treatment of Rauwolfia vomitoria and Gongronema latifolium on neurobehaviour and the neurohistology of the cerebral cortex in mice.

Internet Journal of Medical Update 2015;

10(1):

3-10.

DOI:

http://dx.doi.org/10.4314/ijmu.v10i1.2

40 Avwioro OG. Histochemistry and tissue pathology, principle and techniques.

Claverianum Press, Nigeria, 2010.

https://www.scirp.org >reference>

$\underline{\text { ReferencesPapers }}$

41 Kierszenbaum AL, Tres L. Histology and Cell Biology: An Introduction to Pathology. 3rd ed. Elsevier Saunders, Philadelphia, 2011; 217-9. ISBN: 978-0-323- 07842-9.

https://www.elsevier.com>books $>$ kierszenbaum > 978-0-323-31330-8

42 Bancroft JD, Gamble, M. "Theory and Practice of Histological Technique". (5th Edition).

Churchill Livingstone, Edinburg and London, 2002.https://trove.nla.gov.au/work/10963990

43 Martins LJ, Al-Abdulla NA, Kirsh JR, Sieber FE, Portera-Cailliau C. Neurodegeneration in excitotoxicity, global cerebral ischaemia and target deprivation: A perspective on the contributions of apoptosis and necrosis. Brain Res Bull 1978; 46: 281-309. DOI: 10.1016/s0361-9230(98)00024-0

44 Michael HR, Wojciech P. Histology: A Text and Atlas. 6th ed. Lippincott Williams \& Wilkins, Philadelphia, 2010; 1525.https://trove.nla.gov.au/work/7780768 
45 Bathaie SZ, Mokarizade N, Shirali S. An overview of the mechanisms of plant ingredients in the treatment of diabetes mellitus. Journal of Medicinal Plants 2012; 11(44):1-12

DOI:https://www.sid.ir/en/journal/ViewPaper. aspx?id=289627

46 Davis S. Oral hypoglycaemic drugs for the treatment of type 2 diabetes mellitus. South African Pharmaceutical Journal 2012; 79(3): 22-24.

DOI:https://www.ncbi.nlm.nih.gov/pmc/article s/PMC5903388/

47 Bouchern J, Kleinridders A, Kahn CR. Insulin Receptor Signaling in Normal and InsulinResistant States. Cold Spring Harb Perspect Biol 2014; 6(1): a009191. DOI: $10.1101 /$ cshperspect.a009191
48 Ramesh G. Cytokines and Chemokines at the Crossroads of Neuroinflammation, Neurodegeneration, and Neuropathic Pain. Mediators of Inflammation 2013; 1-20. DOI: $10.1155 / 2013 / 480739$

49 Park JH, Lee SH, Chung IM, Park Y. Sorghum extract exerts an anti-diabetic effect by improving insulin sensitivity via PPAR- $\gamma$ in mice fed a high-fat diet. Nutrition Research and Practice 2012; 6(4):322-327. DOI:http://dx.doi.org/10.4162/nrp.2012.6.4.32 $\underline{2}$

50 Pothuizen HH, Zhang WN, Jongen-Relo AL, Feldon J, Yee BK. "Dissociation of antioxidant status associated woth learning abilities of the experimental animals: a within-subject, within-task comparison of reference and working spatial memory". European Journal of Neuroscience 2004; 19(3): $705-712$.

DOI:https://doi:10.1111/j.0953-

816X.2004.03170.x 